\title{
Technology to the Rescue: Appropriate Curriculum for Gifted Students
}

\author{
Dr. Susan L. Zimlich \\ Southeastern Louisiana University \\ Hammond, Louisiana
}

\begin{abstract}
An appropriate curriculum for students who are gifted will meet their learning needs and motivate them to stay engaged in the learning process. In an effort to provide an appropriate curriculum for gifted students, one possibility is to provide a behavior trap. Behavior traps are learning activities that entice students to engage due to interest in the content or activity itself. Behavior traps motivate because they are easy to do at first and then reinforce motivation later to encourage continued engagement (Albert \& Heward, 1996). Technology can be both a tool to provide a behavior trap and also a behavior trap in and of itself. Students who are gifted benefit when curriculum provides practice with complex topics, critical thinking, self-reflection, creativity, and access to mentors for scaffolding. This is essential for helping students who are gifted to reach their potential. Technology and what can be done with technology in educational settings can provide complexity in differentiated or individualized learning. Students' critical thinking skills and metacognition can be built through problem solving, projects, and simulations enhanced or provided by technology. Students can compare their work with peers in other locations or have access to mentors who might not otherwise be available. Specialized software and equipment can be used to help build academic skills and also develop creativity. Technology can help teachers meet the standards for gifted education programs, but only if teachers choose to implement technology in meaningful ways that meet the needs of students who are gifted.
\end{abstract}

Keywords: Motivating gifted students; educational technology; gifted curriculum; thinking skills.

\section{Introduction}

Technology has taken a firm hold in education. Technology can be taught as a stand-alone topic or embedded within a lesson (Henriksen, Mishra, \& Fisser, 2016; International Society for Technology in Education, 2007). Schools have not only labs, but also computers or tablets in classrooms, interactive white boards, digital cameras, video cameras, computer projectors, and other digital equipment (Lanahan \& Boysen, 2005). Additionally, applications run the gambit from gamestyle formats that use high- tech virtual interactions to teach children an assortment of subjects and thinking skills (Siegle, 2015; Tünzün, 2007; Williams, 
Ma, Feist, Richard, \& Prejean, 2007) to traditional word processing and presentation software. Teachers recognize that technology motivates many students to produce high quality work (Clausen, 2007), and students themselves report that it motivates them to engage with a variety of subject areas and topics of interest (Clausen, 2007; “Digital Imaging," 2001; Johnsen, Witte, \& Robins, 2006; Wighting, 2006). Teachers direct student use of technology in school and can use their decision making power to purposefully plan to use technology in ways that motivate students (Siegle, 2015).

Motivation is shaped by both personal and situational influences (Clinkenbeard, 2012; Little, 2012). Particular attention to the preservation and development of motivation should inform programming for gifted students (Gottfried, Gottfried, Cook, \& Morris, 2005). Teachers should create a setting that encourages students to achieve their full potential. Two key factors in developing potential are motivation and challenge in the learning environment (Little, 2012; National Association for Gifted Children, 2010). Gifted students are motivated by a curriculum that matches their interests and levels of cognitive development (Colangelo \& Davis, 2003; VanTassel-Baska, 2015). When students' goals match their learning environment, they are more likely to stay engaged in schooldirected learning tasks (Kilian, Hofer, \& Kahnle, 2013; Little, 2012). Thus, access to an appropriate curriculum for students who are gifted could have lifelong ramifications.

One possible way to increase students' motivation is through the use of behavior traps. In education, a behavior trap is a learning activity for students that a teacher has created to entice students to be engaged in learning. The behavior trap:

1. is irresistibly attractive to the students,

2. has an easy entry point that is already mastered,

3. reinforces and motivates the students, and

4. uses an activity that sustains the students' interest over time (Albert \& Heward, 1996).

Technology can act as a behavior trap for students who are gifted. It could be that the use of the technology is the behavior trap, or that the technology is a tool for access to content or products that are behavior traps. Today's students have grown up with technology. They experience it in all areas of their lives. The students expect technology to be everywhere, including school. Technology fits the requirements for creating a behavior trap because:

1. it provides access to any topic that might be of interest to students,

2. fluency and expertise with technology are either already mastered or easily mastered by students,

3. access to quick feedback and audiences with similar interests reinforces and motivates students, and

4. access to Web 2.0 capabilities and almost limitless materials about topics can sustain students' interest over time. 


\section{Appropriate Curriculum}

Curriculum plays a large role in determining the context in which teaching and learning occur. All teachers, whether in resource rooms or in general education classrooms, need to provide an appropriate curriculum to meet individual student needs (Kaplan, 2016; Sak, 2004; Smith \& Wietz, 2003; Zentall, Moon, Hall \& Grskovich, 2001). Although in every class there exist differences in the ability, interest, and motivation of students, the flexibility and motivating nature of technology can help create life-giving learning environments (Baule, 2007) by providing students with the opportunity for differentiated instruction or tasks. Differentiation to meet academic needs may come readily to mind; however, it is also important to provide differentiation in terms of creativity. There are many definitions of creativity, but in general students who are creatively gifted are characterized by original thinking that comes from examining a variety of perspectives, using divergent thinking, and thinking in nonlinear ways (Colangelo \& Davis, 2003; Sak, 2004). Some of the most creative students struggle to function within the framework of specialized classes for gifted students where their needs inform instructional planning for the class. How much more do they struggle in the setting of the general education classroom where their needs are often ignored (Sak, 2004)? Teachers who differentiate instruction honor and recognize student strengths, interests, and abilities by providing choices that offer different levels of support for learning. Differentiation of instruction may provide the only opportunities that some gifted students receive to meet their particular learning needs (Bain, Bliss, Choate, \& Brown, 2007; Kaplan, 2016).

Technology can direct and organize student learning (Rosenfeld, 2008). Technology can be used to differentiate lessons when students, rather than teachers, are the ones using it (Garcia \& Rose, 2007; Ysseldyke \& Bolt, 2007). Projects that require technology can engage collaborative groups (Donovan, Hartley, \& Strudler, 2007; Garcia \& Rose, 2007; Wolsey \& Grisham, 2007; Yang, Chang, Cheng, \& Chan, 2016). While some students are working more closely with the teacher, other students can work independently, researching different topics and using a variety of tools to produce distinct products (Smith \& Wietz, 2003). Differentiation of subject matter, topic complexity, and products are all possible natural side effects of assigning projects that use technology.

The role of the teacher is to compact the required curriculum to provide time for a curriculum that better matches students' academic and creative abilities and growth. Technology helps teachers to provide an appropriate curriculum in terms of complexity, higher order thinking skills, and specialized resources, including the use of special software and access to mentors.

\section{Complexity}

Differentiating the levels or types of complexity benefits gifted students, who are more engaged in learning when they encounter tasks that emphasize challenge (Betts, Tardrew, \& Ysseldyke, 2004; Harrison, 2004; Kimball, 2001), complexity ("Digital Imaging," 2001; Harrison, 2004), and high levels of learning (Kimball, 2001; Wighting, 2006). Technology can offer access to materials at all levels of complexity, so students can find information at the level they prefer. Gifted 
students move relatively quickly from concrete ideas to more abstract ideas compared to other students (Harrison, 2004; Smith \& Wietz, 2003). Advanced software can allow students to process all kinds of information and transform it to suit their purposes. Gifted students not only seek out complex ideas, but also want to express their own complex ideas in unique and elaborate ways.

Gifted students rapidly master basic information in a discipline and quickly move to abstract thinking across levels. Technology facilitates making connections among ideas that originate in a variety of materials (Sak, 2004). These new connections give students who are gifted ideas about what to research or how to treat theories (Harrison, 2004).

Students build greater complexity in their products as they gain skill in using technology. The more they appear competent and the more sophisticated the technology they use it, the more exposure to technology they have (Dove \& Zitkovich, 2003). Teachers can model the use of advanced software in lessons that introduce it at basic skill levels. As students acquire skills with the software, teachers can assign projects that require greater complexity ("Digital Imaging," 2001). Teachers can scaffold students' skills in gathering data, editing written work, and publishing products. Because gifted students seek out complexity not just in the way their ideas are expressed, but also in the process of developing the products that demonstrate what they have learned, teachers can encourage student collaboration in initial stages of projects and then gradually let students work on their own.

\section{Critical Thinking Skills}

Thinking skills are another focus of differentiated curriculum for gifted students. All students benefit from developing higher order thinking skills, and good teachers include as many higher order thinking tasks as possible in the regular curriculum (International Society for Technology in Education, 2007; Siegle, 2004). For gifted students, however, higher order thinking skills are the sine qua non of education (Colangelo \& Davis, 2003; Kimball, 2001). Successful use of technology can increase students' confidence and skill levels in critical thinking (Reid \& Roberts, 2006). Furthermore, the stimulation of higher order thinking skills may keep gifted students engaged in school tasks.

Among the most common approaches to the development of critical thinking skills instructions are problem-based learning and project creation, both of which benefit from the infusion of technology. Students who spend more time online show greater skill levels in evaluation and writing (Ba, Tally, \& Tsikalas, 2002). Some software applications are designed to use problem-based learning to teach students specific critical thinking skills (Tünzün, 2007; Williams et al., 2007). Teachers encourage critical thinking by promoting inquiry, by asking questions to help students troubleshoot technology problems, and by limiting the number of questions they answer directly (Ba et al., 2002; "Digital Imaging," 2001; Clausen, 2007; Wong, Quek, Divaharan, Liu, Peer, \& Williams, 2006; Smith \& Weitz, 2003). Reviewing Internet content for reliability is an essential technology skill that also promotes critical thinking (Abelman, 2007). Evaluating the technology with which 
they are interacting (Abelman, 2007; Siegle, 2004), determining the most suitable piece of equipment, program, or tool ("Digital Imaging," 2001), and learning how to balance schoolwork and recreation time on the computer all call for higher order thinking (Ba et al., 2002; Tünzün, 2007).

Technology can change the ways students think about and organize information (Zentall et al., 2001). The development of concepts and connections within and between diverse subject areas, to which Internet access greatly contributes, depends on higher order thinking (Boon, Fore, \& Rasheed, 2007). In the course of working on almost any complex project, students will organize computer files into folders, which helps them understand both how concepts are connected within subject areas and the structure of particular branches of knowledge (Ba et al., 2002; Boon et al., 2007). Technology's ability to have multiple program windows open at the same time eases side-by-side comparisons, facilitating analysis and synthesis of ideas (Sak, 2004). Some problem-based virtual learning environments develop analogical thinking using side-by-side analogies (Tünzün, 2007; Williams et al., 2007).

Technology can also create a context for problem solving particularly suited to creatively gifted students. These students typically examine concepts from a variety of perspectives (Sak, 2004) and often think about them in unusual ways (Fleith, 2000; Russo, 2004). Computer simulations designed to help students practice perspective-taking often present problems from a variety of viewpoints (Tünzün, 2007). Hyperlinks or multi-nodal simulations stimulate nonlinear thinking, which in turn fosters sensitivity toward and appreciation of unusual, creative, and divergent approaches to problem solving by academically and creatively gifted students, who use more cognitive strategies while problem solving than average students (Hong \& Aqui, 2004).

Gifted students are not necessarily highly able in all subject areas (Colangelo, \& Davis, 2003; Swiatek \& Lupkowski-Shoplik, 2000). Although, many of them read above grade level, not all do (Smith \& Weitz, 2003). Most report that they are bored by standard classroom reading activities, regardless of their actual reading ability (Hettinger \& Knapp, 2001), since the vast majority of such tasks focus on lower-order thinking skills (Moon, Callahan, \& Tomlinson, 2003). Many find it more motivating to access material that would otherwise be unavailable (Olszewski-Kubilius \& Lee, 2004), or to collaborate on a common project with students geographically distant from their school (Wong et al., 2006, Yang et al., 2016) on topics that interest them (Zentall et al., 2001). Reading advanced, highly interesting material online may benefit gifted students, even those who have learning disabilities in reading, more than reading yet another story from a basal reader (Zentall et al., 2001). Collaborating with an online group gives students access to others far distant from their localities who share their interests. Some may have greater ability or more expertise and thus able to scaffold learning of knowledge or skills (Yang et al., 2016). Furthermore, the possibility of collaboration online gives students a choice about working independently or in a group (Wong et al., 2006). 
Technology may also aid in the development of metacognition, as it can be a resource for reflection and feedback as well as for investigation (Harrison, 2004). Training in metacognition is an important part of gifted curriculum, as it stimulates creativity, problem solving fluency, and self-regulation (Colangelo \& Davis, 2003). Metacognition and self-reflection are enhanced when students are made aware of available strategies, and then are given open-ended meaningful tasks in which to use the strategies (Kinnebrew, Segedy, \& Biswas, 2014; Paris \& Paris, 2001). Web 2.0 technologies allow students plentiful options for tasks that can be shared beyond the classroom walls, such as publishing a blog, collaborating on research, and exploring opportunities for service learning. Additionally, technology can allow for independence and choice in learning tasks, characteristics that enhance the development of self-regulation in students (Paris \& Paris, 2001). Overestimation or underestimation of skills are improved through feedback on work (Callender, Franco-Watkins, \& Roberts, 2015). Technology can provide immediate feedback to students, as well as give students access to feedback sources beyond their classroom teacher. Students who are gifted have a better sense of their own skills when they can compare their work to peers or experts.

\section{Mentors}

Mentoring is an aspect of gifted education (Colangelo \& Davis, 2003) that is greatly enhanced through technology. Gifted students seek out mentors (Colangelo \& Davis, 2003). Technology allows a student access to a mentor no matter what the subject area, level of expertise, or geographical constraint. Expert mentors are available from all over the world via the Internet (Housand \& Housand, 2012; Mammadov \& Topcu, 2014; Olthouse \& Miller, 2012). Email, webcams, blogs, wikis, and instant messaging make communication fast and easy. Through such technologies, students can function as research aides alongside scientists, historical writers, or mathematicians. Such opportunities help them develop an understanding of what experts do in the field.

Creatively gifted students' ratings of creativity have high correlation with those of experts, but as novices, they need mentoring to learn how to provide and receive feedback about how to improve their products. Mentors teach them ways to express why one product is more creative than another (Dove \& Zitkovich, 2003; Mammadov \& Topcu, 2014). Communication with mentors can help students develop understandings of their own creativity by modeling and providing meaningful creative feedback (Kaufman, Gentile, \& Baer, 2005).

Mentors are a good resource for acceleration, guiding work when students' zones of proximal development are beyond the classroom teachers' competence. Mentors can help academically able learners advance to higher levels of skill through discussions of hands-on learning and independent projects (Dove \& Zitkovich, 2003; Wong et al., 2006).

\section{Specialized Software and Equipment}

The curriculum for gifted students should include opportunities to learn about and use specialized software or equipment to reflect their thinking patterns. Instruction can have technology skill as an end in itself, but it can also be a tool for motivating students to engage in high levels of academic work ("Digital 
Imaging," 2001; Johnsen et al., 2006; Wighting, 2006). The multimedia aspects of software can help students express ideas using sounds, pictures, diagrams, text, and combinations of those media. The motivation can come from using software features (Boon et al., 2007) or from using specialized equipment (Dove \& Zitkovich, 2003).

The ways in which technology is used can reflect the areas of giftedness, whether academic or creative (Zentall et al., 2001). Students who are more academically gifted typically produce fewer original materials than creatively gifted students, but they demonstrate a greater aptitude for managing information and academic achievement (Sak, 2004). They often use software in ways that reflect linear thinking. In some software, part of the design structure of the program is to scaffold student learning (Williams et al., 2007). Learning is enhanced when software facilitates study and/or provides course-related materials (Betts et al., 2004; Boon et al., 2007; Olszewski-Kubilius \& Lee, 2004; Siegle \& Foster, 2001). Software has even been written with the aim of increasing levels of metacognition by students (Kinnebrew et al., 2014).

Creative students display originality, curiosity (Fleith, 2000; Harrison, 2004; Sak, 2004), and nonconformity, both in their classroom interactions and in their thinking patterns. Such students easily take on other viewpoints (Zentall et al., 2001), a skill which can be encouraged using technology. Hyperlinks and multiple windows reflect their nonlinear thinking. For example, gifted student writers make extensive use of software functions that find synonyms to experiment with how particular words change the meaning of a sentence (Sak, 2004).

Games may be tied to standards and sometimes may directly teach or reinforce skills when students answer questions and get immediate feedback (Siegle 2015). Interactive games are a form of specialized game software that can offer virtual learning environments with content that appeals to academically gifted students. They often have an overarching, linear storyline, but feature game play that is multi-nodal in nature, attracting creatively gifted students. The self-selected quests and the multiple ways to explore the gaming environment promote the kinds of higher order thinking privileged by gifted and talented curriculum (Tünzün, 2007; Williams et al., 2007).

Software can also individualize the educational experience. Programs paired with paper and pencil assignments, such as those created by Accelerated Math, track student progress and offer learning activities for specific levels of performance (Betts et al., 2004; Ysseldyke \& Bolt, 2007). In immersive educational computer games, student choice produces avatars and results in individualized experiences of tasks and levels of game play (Tünzün, 2007; Williams et al., 2007).

Computer simulations are an especially helpful kind of software. They are immersive virtual learning environments that mimic real life, feature real-time interactions, and provide immediate feedback (Mohide, Matthey-Maich, \& Cross, 2006; Tünzün, 2007; Williams et al., 2007). They facilitate problem-based learning by helping students collaborate to solve the problems encountered in the 
simulation. They provide a contextualization of the problems presented within the content-laden storyline of the game (Mohide et al., 2006; Tünzün, 2007). For example, they can help students explore the technologies, occupations, governments, or lifestyles of different historical periods. Finally, they stimulate students' imaginations and show the depth of detailed knowledge needed to plan an invention or create a fictional country.

In addition to specialized software, there are numerous pieces of specialized equipment that use computer processing. Using Global Positioning Systems or other equipment that adults use can excite and motivate students (Dove \& Zitkovich, 2003).

In summary, the full development of gifted students' potential requires an appropriate curriculum. Technology can help teachers offer a curriculum differentiated by complexity, a focus on thinking skills, and opportunities to learn about and use specialized software and equipment or access to mentors.

\section{Conclusion}

It is fitting that teachers of the gifted use technology in delivery of content for their students (National Association for Gifted Children, 2013). Technology can help teachers foster the motivation of high-end learners. Both digital literacy and gifted education emphasize creativity, innovation, collaboration, critical thinking, problem solving, and decision making. This overlap allows teachers to help students develop in both areas simultaneously through strategic use of technology in the classroom (Henriksen et al., 2016; International Society for Technology in Education, 2007; Siegle, 2004). Differentiating lessons by complexity, critical thinking, and challenge (Kaplan, 2016) will highly motivate gifted students to better meet their needs and help them to achieve to their full potential (Little, 2012).

In particular, using technology to structure the learning environment in ways that ensure an appropriate curriculum can act as a behavior trap (Albert \& Heward, 1996) to motivate high-end learners. The ways that technology can aid students in accessing materials within their zone of proximal development and in allowing students to create increasingly complex products means that technology facilitates the behavior trap requirement of an easily mastered entry point. Additionally, teaching strategies such as problem-based learning, inquiry methods, and development of students' conceptual skills in organization and metacognition, require critical thinking and are supported by technology. Critical thinking provides challenge that is irresistibly attractive for gifted students, another requirement of a behavior trap. Mentors, who are readily accessible using technology, can help meet the behavior trap requirement of providing reinforcement and motivation for gifted students. In addition to easy access to volumes of materials online, the specialized equipment and specialized software that allow students to demonstrate varying levels of expertise, display creativity, or experience alternate realities meets the final behavior trap requirement of sustaining student interest over time. Teachers can use technology as a tool to help meet the needs of students who are gifted. 


\section{References}

Abelman, R. (2007). Fighting the war on indecency: Mediating TV, internet, and videogame usage among achieving and underachieving gifted children. Roeper Review, 29, 100-112. https://doi.org/10.1080/02783190709554393

Albert, S. R., \& Heward, W. L. (1996). Gotcha! Twenty-five behavior traps guaranteed to extend your students' academic and social skills. Intervention in School \& Clinic, 31, 285-289. https://doi.org/10.1177/105345129603100505

Ba, H., Tally, W., \& Tsikalas, K. (2002). Investigating children's emerging digital literacies. The Journal of Technology, Learning and Assessment, 1(4). Retrieved from http://ejournals.bc.edu/ojs/index.php/jtla/article/view/1670/1510

Bain, S. K., Bliss, S. L., Choate, S. M., \& Brown, K. S. (2007). Serving children who are gifted: Perceptions of undergraduates planning to become teachers. Journal for the Education of the Gifted, 30(4), 450-478.

https://doi.org/10.4219/jeg-2007-506

Baule, S. M. (2007). The components of successful technology. Teacher Librarian, 34 (5), 1618.

Betts, J., Tardrew, S., \& Ysseldyke, J. (2004). Use of an instructional management system to enhance math instruction of gifted and talented students. Journal of Education of the Gifted, 27, 293-310. https:// doi.org/10.4219/jeg-2004-319

Boon, R. T., Fore, C., \& Rasheed, S. (2007). Students' attitudes and perceptions toward technology-based applications and guided notes instruction in high school world history classrooms. Reading Improvement, 4(1), 23-31.

Callendar, A. A., Franco-Watkins, A. M., \& Roberts, A. S. (2015). Improving metacognition in the classroom through instruction, training, and feedback. Metacognition Learning 11, 215-235. https://doi.org/10.1007/s11409-015-9142-6

Clausen, J. M. (2007). Beginning teachers' technology use: First-year teacher development and the institutional context's affect on new teachers' technology use with students. Journal of Research on Technology in Education, 39, 245-261. https://doi.org/10.1080/15391523.2007.10782482

Clinkenbeard, P. R. (2012). Motivation and gifted students: Implications of theory and research. Psychology in the Schools, 49, 622-630. https:// doi.org/10.1002/pits.21628

Colangelo, N., \& Davis, G. A. (Eds.). (2003). Handbook of gifted education (3 $3^{\text {rd }}$ ed.). Boston: Allyn and Bacon.

Digital imaging supplement- shape: Adobe After Effects, Adobe Photoshop and Adobe Premier used in Savannah R-III Elementary School. (2001). T.H.E. Journal, 29 (3), 66.

Donovan, L., Hartley, K., \& Strudler, N. (2007). Teacher concerns during initial implementation of a one-to-one laptop initiative at the middle school level. Journal of Research on Technology in Education, 39, 263-286. https://doi.org/10.1080/15391523.2007.10782483

Dove, M. K., \& Zitkovich, J. A. (2003). Technology driven group investigations for gifted elementary students. Information Technology in Childhood Education, 2003(1), 223241.

Fleith, D. d. F. (2000). Teacher and students' perceptions of creativity in the classroom environment. Roeper Review, 22, 148-153. https://doi.org/10.1080/02783190009554022

Garcia, P., \& Rose, S. (2007). The influence of technocentric collaboration on preservice teachers' attitudes about technology's role in powerful learning and teaching. Journal of Technology and Teacher Education, 15, 247-266.

Gottfried, A. W., Gottfried, A. E., Cook, C. R., \& Morris, P. E. (2005). Educational characteristics of adolescents with gifted academic intrinsic motivation: A 
longitudinal investigation from school entry through early adulthood. Gifted Child Quarterly, 49, 172-186. https://doi.org/10.1177/001698620504900206

Harrison, C. (2004). Giftedness in early childhood: The search for complexity and connection. Roeper Review, 26, 78-84. https:// doi.org/10.1080/02783190409554246

Henriksen, D., Mishra, P., \& Fisser, P. (2016). Infusing creativity and technology in $21^{\text {st }}$ century education: A systematic view for change. Educational Technology \& Society, 19(3), 27-37.

Hettinger, H. R., \& Knapp, N. F., (2001). Potential, performance, and paradox: A case study of J. P., a verbally gifted struggling reader. Journal for the Education of the Gifted, 24, 248-289. https:// doi.org/10.1177/016235320102400303

Hong, E., \& Aqui, Y. (2004). Cognitive and motivational characteristics of adolescents gifted in mathematics: Comparisons among students with different types of giftedness. Gifted Child Quarterly, 48, 191- 201. https://doi.org/10.1177/001698620404800304

Housand, B. C., \& Housand, A. M. (2012). The role of technology in gifted students' motivation. Psychology in the Schools, 49, 706-715. https://doi.org/10.1002/pits.21629

International Society for Technology in Education. (2007). National Education Technology Standards for Students. Retrieved from http://www.cnets.iste.org/standards/standards/for-students

Johnsen, S. K., Witte, M., \& Robins, J. (2006). Through their eyes: Students' perspectives of a university-based enrichment program - The University for Young People Project. Gifted Child Today, 29 (3), 56-61. https://doi.org/10.4219/gct-2006-5

Kaplan, S. N. (2016). Challenge vs. differentiation: Why, what and how. Gifted Child Today 39(2), 114-15. https://doi.org/10.1177/1076217516628916

Kaufman, J. C., Gentile, C. A., \& Baer, J. (2005). Do gifted student writers and creative writing experts rate creativity the same way? Gifted Child Quarterly, 49, 260-265. https://doi.org/10.1177/001698620504900307

Kilian, B., Hofer, M., \& Kahnle, C. (2013). Conflicts between on-task and off-task behaviors in the classroom: The influences of parental monitoring, peer value orientations, students' goals, and their value orientations. Social Psychology of Education, 16(1), 77-94. https://doi.org/10.1007/s11218-012-9198-y

Kimball, K. L. B. (2001). Interpretative stories from school careers of gifted students. Retrieved from ProQuest database. (AAT 3032075)

Kinnebrew, J. S., Segedy, J. R., \& Biswas, G. (2014). Analyzing the temporal evolution of students' behavior in open-ended learning environments. Metacognition \& Learning 9(2), 187-215. https://doi.org/10.1007/s11409-014-9112-4

Lanahan, L., \& Boysen, J. (2005). Computer technology in the public school classroom: Teacher perspectives. (NCES 2005-083). Washington, DC: National Center for Education Statistics. Retrieved from http://nces.ed.gov/pubs2005/2005083.pdf

Little, C. A. (2012). Curriculum as motivation for gifted students. Psychology in the schools, 49, 695-705. https://doi.org/10.1002/pits.21621

Mammadov, S. \& Topcu, A. (2014). The role of e-mentoring in mathematically gifted students' academic life: A case study. Journal for the Education of the Gifted, 37(3), 220-244. https://doi.org/10.1177/0162353214540824

Mohide, E. A., Matthew-Maich, N., \& Cross, H. (2006). Using electronic gaming to promote evidence-based practice in nursing education. Journal of Nursing Education, 45, 384.

Moon, T. R., Callahan, C. M., \& Tomlinson, C. A. (2003). Effects of state testing program on elementary schools with high concentration of student poverty- Good news or bad news? Current Issues in Education, 6(8). Retrieved from http://cie.asu.edu/volume6/number8/

National Association for Gifted Children. (2010). 2010 pre-K-grade 12 gifted programming 
standards. Retrieved from

http://www.nagc.org/sites/default/files/standards/K-

12\%20programming $\% 20$ standards.pdf

National Association for Gifted Children. (2013). NAGC-CEC teacher preparation standards in gifted and talented education. Retrieved from http://www.nagc.org/sites/default/files/standards/NAGC\%20CEC $\% 20$ CAEP $\% 20$ standards $\% 20(2013 \% 20$ final).pdf

Olszewski-Kubilius, P., \& Lee, S. Y. (2004). Gifted adolescents' talent development through distance learning. Journal for the Education of the Gifted, 28(1), 7-35. https://doi.org/10.1177/016235320402800102

Olthouse, J. M., \& Miller, M. T. (2012). Teaching talented writers with web 2.0 tools. Teaching Exceptional Children, 45(2), 6-14. https://doi.org/10.1177/004005991204500201

Paris, S. G., \& Paris, A. H. (2001). Classroom applications of research on self-regulated learning. Educational Psychologist 36(2), 89-101. https://doi.org/10.1207/s15326985ep3602_4

Reid, P. T., \& Roberts, S. K. (2006). Gaining Options: A Mathematics Program for Potentially Talented At-risk Adolescent Girls. Merrill-Palmer Quarterly, 52, 288304. https://doi.org/10.1353/mpq.2006.0019

Rosenfeld, B. (2008). The challenges of teaching with technology: From computer idiocy to computer competence. International Journal of Instructional Media, 35, 157-166.

Russo, C. F. (2004). A comparative study of creativity and cognitive problem-solving strategies of high-IQ and average students. Gifted Child Quarterly, 48, 179-190. https://doi.org/10.1177/001698620404800303

Sak, U. (2004). About creativity, giftedness, and teaching the creatively gifted in the classroom. Roeper Review, 26, 216-222. https://doi.org/10.1080/02783190409554272

Siegle, D. (2004). The merging of literacy and technology in the 21 ${ }^{\text {st }}$ century: A bonus for gifted education. Gifted Child Today, 27(2), 32-35. https://doi.org/10.4219/gct-2004-129

Siegle, D. (2015). Technology. Gifted Child Today, 38(3), 192-197. https://doi.org/10.1177/1076217515583744

Siegle, D., \& Foster, (2001). Laptop computers and multimedia and presentation software: Their effects on student achievement in anatomy and physiology. Journal of Research on Technology in Education, 34(1), 29-37. https://doi.org/10.1080/15391523.2001.10782331

Smith, K. \& Weitz, M. (2003). Problem Solving Education and Gifted Education: A Differentiated Fifth-Grade Fantasy Unit. Gifted Child Today, 26(3), 56-60. https://doi.org/10.4219/gct-2003-108

Swiatek, M. A., \& Lupkowski-Sholik, A. (2000). Gender differences in academic attitudes among gifted elementary school students. Journal for the Education of the Gifted, 23, 360-377. https:// doi.org/10.1177/016235320002300403

Tünzün, H. (2007). Blending video games with learning: Issues and challenges with classroom implementations in the Turkish context. British Journal of Educational Technology, 38, 465-477. https://doi.org/10.1111/j.1467-8535.2007.00710.x

VanTassel-Baska, J. (2015). Curriculum issues: Error analysis in thinking about curriculum for the gifted. Gifted Child Today, 38(3), 198-199. https:// doi.org/10.1177/1076217515583746

Wighting, M. J. (2006). Effects of Computer Use on High School Students' Sense of Community. The Journal of Educational Research, 99, 371-379. https://doi.org/10.3200/joer.99.6.371-380

Williams, D., Ma, Y., Feist, S., Richard, C. E., \& Prejean, L. (2007). The design of an analogical encoding tool for game-based virtual learning environments. British 
Journal of Educational Technology, 38, 429-437.

https://doi.org/10.1111/j.1467-8535.2007.00707.x

Wolsey, T. D., \& Grisham, D. L. (2007). Adolescents and the new literacies: Writing engagement. Action in Teacher Education, 29(2), 29-38. https://doi.org/10.1080/01626620.2007.10463446

Wong, A. F. L., Quek, C. L., Divaharan, S., Liu, W. C., Peer, J., \& Williams, M. D. (2006). Singapore Students' and Teachers' Perceptions of Computer-Supported Project Work Classroom Learning Environments. Journal of Research on Technology in Education, 38, 449-479. https:// doi.org/10.1080/15391523.2006.10782469

Yang, E. F. Y., Chang, B., Cheng, H. N. H., \& Chan, T. (2016). Improving pupils' mathematical communication abilities through computer-supported reciprocal peer tutoring. Educational Technology \& Society, 19(3), 157-169.

Ysseldyke, J., \& Bolt, D. M. (2007). Effect of technology-enhanced continuous progress monitoring on math achievement. School Psychology Review, 36, 453-467.

Zentall, S. S., Moon, S. M., Hall, A. M., \& Grskovich, J. A. (2001). Learning and motivational characteristics of boys with $\mathrm{AD} / \mathrm{HD}$ and/or giftedness. Exceptional Children, 67(4), 499-519. https://doi.org/10.1177/001440290106700405 